\title{
Endovascular management of episiotomy site hematoma: Two cases and a brief review
}

\section{Epizyotomi bölgesi hematomunun endovasküler yönetimi: İki hasta ve kisa bir inceleme}

\author{
(1) Swati Shivhare ${ }^{1}$, (1) Jyoti Meena ${ }^{1}$, (1) Sunesh Kumar ${ }^{1}$, (1) Shivanand Gamanagatti ${ }^{2}$ \\ ${ }^{1}$ All India India Institute of Medical Sciences, Department of Obstetrics and Gynecology, New Delhi, India \\ ${ }^{2}$ All India India Institute of Medical Sciences, Department of Radiology, New Delhi, India
}

\begin{abstract}
Episiotomy site hematoma, though uncommon, can be associated with serious maternal morbidity. It arises mostly due to tissue trauma or injury to blood vessels, leading to the formation of a pseudoaneurysm. Sometimes, when surgical management fails, embolization of the bleeding vessel is a lifesaving option. Here, we report two cases of episiotomy site hematoma that required selective arterial embolization for management, following the failure of surgical management. A 28-year-old G6A5 woman underwent forceps delivery following which she developed a 6*6-cm right-sided vulvovaginal hematoma at the episiotomy site. After failed surgical management, arterial embolization was performed and hemostasis was achieved. A 26-year-old P2L2 woman with a history of surgical exploration for episiotomy site hematoma, presented postdelivery on postpartum day seven with profuse vaginal bleeding. Her computed tomography angiogram revealed a pseudoaneurysm of around $2.1 * 1 \mathrm{~cm}$ in length with a vaginal hematoma of $4 * 5 \mathrm{~cm}$. Selective artery embolization performed and complete hemostasis was achieved with no complications. Selective arterial embolization is a safe therapeutic option for episiotomy site hematoma, especially if surgical management fails.
\end{abstract}

Keywords: Pseudoaneurysm, episiotomy site hematoma, selective artery embolization

$\ddot{\mathrm{O} z}$

Epizyotomi bölgesi hematomu nadir de olsa ciddi maternal morbidite ile ilişkilendirilebilir. Çoğunlukla doku travmasına bağlı olarak ortaya çıkar veya kan damarının yaralanmasına bağlı olarak psödoanevrizma oluşumuna neden olabilir. Bazen, cerrahi tedavi başarısız olduğunda, kanayan damarın embolizasyonu hayat kurtaran bir seçenektir. Burada, cerrahi tedavinin başarısızlı̆̆ını takiben tedavi için selektif arteriyel embolizasyon gerektiren iki epizyotomi bölgesi hematomlu hasta bildiriyoruz. Yirmi sekiz yaşındaki G6A5 olan hasta forsepsle doğum yaptı ve ardından epizyotomi bölgesinde 6*6 cm boyutlarında sağ vulvovajinal hematom geliștirdi. Başarısız bir cerrahi tedaviden sonra arteriyel embolizasyon yapıldı ve hemostaz sağlandı. Epizyotomi yeri hematomu için cerrahi eksplorasyon öyküsü olan 26 yaşındaki P2L2 olan hasta doğum sonrası yedinci günde bol vajinal kanama ile başvurdu. BT anjiyografide yaklaşı $2,1 * 1 \mathrm{~cm}$ boyutlarında psödoanevrizma ve $4 * 5 \mathrm{~cm}$ boyutlarında vajinal hematom saptandı. Selektif arter embolizasyonu yapıldı ve komplikasyonsuz tam hemostaz sağlandı. Selektif arteriyel embolizasyon, özellikle cerrahi tedavi başarısız olursa epizyotomi bölgesi hematomu için güvenli bir tedavi seçeneğidir.

Anahtar Kelimeler: Psödoanevrizma, epizyotomi bölgesi hematomu, selektif arter embolizasyonu

\section{Introduction}

Postpartum vulvovaginal hematomas are potentially lifethreatening obstetric complications of vaginal delivery, most commonly presenting with episiotomy site swelling or hemorrhage. The management depends on the size of the hematoma and usually consists of incision and drainage of the hematoma with ligation of the bleeding vessels, followed by packing. Recurrent vaginal hematoma and episiotomy site pseudoaneurysm are rare complications that occur with episiotomy, mainly due to failed surgical management.

Pseudoaneurysms arise from disruption of arterial wall continuity by inflammation or events such as vascular trauma. Pseudoaneurysms differ from aneurysms in that they have a single layer of connective tissue, unlike true aneurysms, which have a three-layer wall ${ }^{(1)}$. Pseudoaneurysms can rupture due to high pressure in the artery, which can cause extravasation of blood through the connective tissue thus, leading to life-

Address for Correspondence/Yazışma Adresi: Assoc. Prof. Jyoti Meena,

All India India Institute of Medical Sciences, Department of Obstetrics and Gynecology, New Delhi, India

Phone: 011-40391032 E-mail: drjyotirajesh@gmail.com ORCID ID: orcid.org/0000-0002-8364-0737

Received/Geliș Tarihi: 21.11.2020 Accepted/Kabul Tarihi: 21.02.2021

${ }^{\oplus}$ Copyright 2021 by Turkish Society of Obstetrics and Gynecology

Turkish Journal of Obstetrics and Gynecology published by Galenos Publishing House 
threatening vaginal bleeding or hematoma. Rapid progression of labor with vacuum or forceps delivery is a probable risk factor for vaginal pseudoaneurysm ${ }^{(2)}$.

Here we report two unusual cases of episiotomy site haematoma following vaginal delivery managed successfully by selective arterial embolization.

\section{Case 1}

A G6A5 28-year-old female with a 38+5 weeks' gestation known case of sickle cell anemia with beta-thalassemia trait and intrahepatic cholestasis of pregnancy came to our emergency department in labor. Her hemoglobin was $8 \mathrm{~g} / \mathrm{dL}$, platelet count was $1.4 * 10^{5}$, and her coagulation profile was normal at the time of admission. She underwent a forceps delivery and had atonic postpartum haemorrhage after delivery, which was medically managed. Soon she developed a right vulvovaginal hematoma of around $6 * 6 \mathrm{~cm}$ at the episiotomy site. Her hemoglobin dropped to $5.8 \mathrm{~g} / \mathrm{dL}$ from the $8 \mathrm{~g} / \mathrm{dL}$ and she had tachycardia of 120 beats/minute.

Surgical exploration of the hematoma was performed under anaesthesia, but immediately after the procedure, she again developed hematoma and bleeding from the episiotomy site. Surgical re-exploration was performed in the same procedure, no active bleeder was found. Accordingly, the dead space was obliterated and hemostasis achieved, but hematoma formed again at the same site. Thus, the decision for selective artery embolization was taken after discussing with the interventional radiologist in view of recurrent hematoma and intractable bleeding from the episiotomy site. Transcatheter embolization was performed on a digital subtraction angiography unit (Artis Zee® Siemens Medical Solutions, Erlangen, Germany). A 5-F diagnostic angiographic catheter was used to access the internal iliac artery. A renal double-curve or Picard catheter (Cook Medical, Bloomington, Indiana) was used to access the contralateral internal iliac artery and a SIMl catheter was used for accessing the ipsilateral internal iliac artery. A 2.7F microcatheter (Progreat microcatheter, Terumo Medical, Somerset, NJ) was used for super-selective catheterization of the uterine artery and its branches. A selective angiogram of both internal pudendal artery was performed, but it revealed no active contrast extravasation; however, an abnormal blush was noted, which was embolized using gelfoam (Spongostan, Ferrosan Medical Devices A/S, Søborg, Denmark) and the bleeding stopped immediately after the procedure (Figure 1). The patient was transfused with 3 units of packed red blood cells (PRBC) and 8 units of fresh frozen plasma (FFP) intra and post-operatively. On post-operative day eight, a $3-\mathrm{cm}$ gaping superficial episiotomy was noticed, but conservative management was performed for the patient and she was discharged on day 24 in a healthy condition with a healing episiotomy site, by secondary intention.

\section{Case 2}

A 26-year-old P2L2 woman was referred to our emergency department after an episode of profuse vaginal bleeding on postpartum day seven, following a spontaneous vaginal delivery for further management. She had one previous cesarean section and was diagnosed as having gestational diabetes mellitus in this pregnancy, which was managed with insulin. She had a full-term normal vaginal delivery with right mediolateral episiotomy at a private centre. Three hours after delivery, the patient developed swelling of around $6^{*} 6 \mathrm{~cm}$ in the right vulvovaginal region at the episiotomy site with profuse vaginal bleeding. As per the records of the hospital from where she was referred, surgical exploration was performed and hemostasis was achieved, she received 6 units of PRBC and 4 units of FFP intraoperatively and was kept in the intensive care unit (ICU) for 2 days.

On post-partum day seven, she again had an episode of profuse bleeding from the episiotomy site, an ultrasound (USG) Doppler was performed, which suggested an arterio-venous (AV) malformation. For immediate management, vaginal packing was performed, 10 PRBC and 10 FFP were transfused and she was transferred to our tertiary care hospital. In our emergency department, the initial evaluation of the patient revealed tachycardia of 112 beats/minute, blood pressure-110/70 mm Hg,

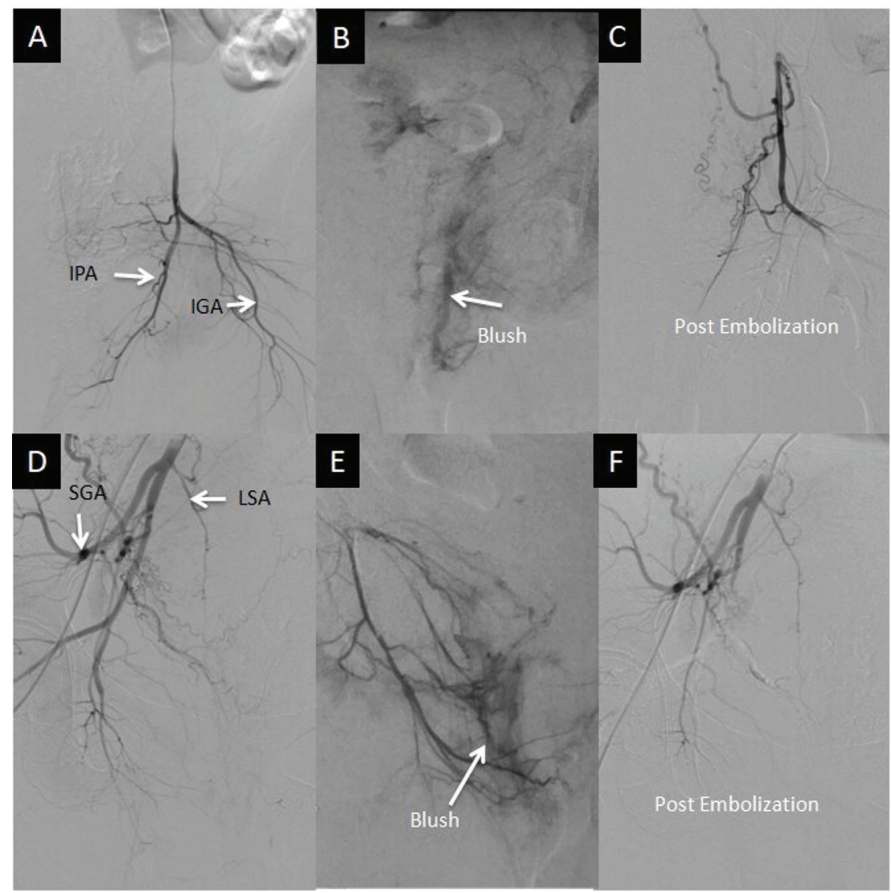

Figure 1. DSA spots of both internal pudendal artery angiograms $(\mathrm{A}, \mathrm{D})$ showing no active contrast extravasation; however, there was abnormal blush (arrow) noted (B, E), which was embolized using gelfoam. Post embolization angiograms (C, F) showed a significant reduction of the abnormal blush

IPA: Internal pudendal artery, IGA: Inferior gluteal artery, SGA: Superior gluteal artery, LSA: Lateral sacral artery 
and moderate pallor. All baseline investigations were sent, her hemoglobin was $7.4 \mathrm{~g} / \mathrm{dL}$ and TLC 24,900/L. One unit of PRBC and three units of FFP was transfused to the patient and she was started on broad-spectrum antibiotics.

Initially, USG Doppler was performed which suggested a pseudoaneurysm, then computed tomography (CT) angiography was performed, which revealed pseudoaneurysm of $2.1^{*} 1 \mathrm{~cm}$ in relation to the episiotomy site on the right posterolateral wall of the upper vagina, likely from the small branches of the anterior division of internal iliac artery (vaginal artery) (Figure $2 \mathrm{~A} \& \mathrm{~B}$ ). There was a pelvic hematoma of around $4 * 5 \mathrm{~cm}$ just lateral to pseudoaneurysm and the upper vagina was distended with clots (Figure $2 \mathrm{~A} \& \mathrm{~B}$ ), along with the vaginal pack. The decision for embolization was taken in view of the CT pseudoaneurysm findings. Percutaneous thrombin injection into the pseudoaneurysm was attempted, but it was not successful. Hence, transcatheter embolization was performed through the right transfemoral route. A $-5 \mathrm{~F}$ diagnostic angiographic SIMl catheter (Cook Medical, Bloomington, Indiana) was used to access the ipsilateral internal iliac artery and co-axial microcatheter system (Progreat microcatheter, Terumo Medical, Somerset, NJ) for super-selective catheterization of the vaginal branch of the right internal iliac artery and embolization of pseudoaneurysm was performed using 30\% glue injection

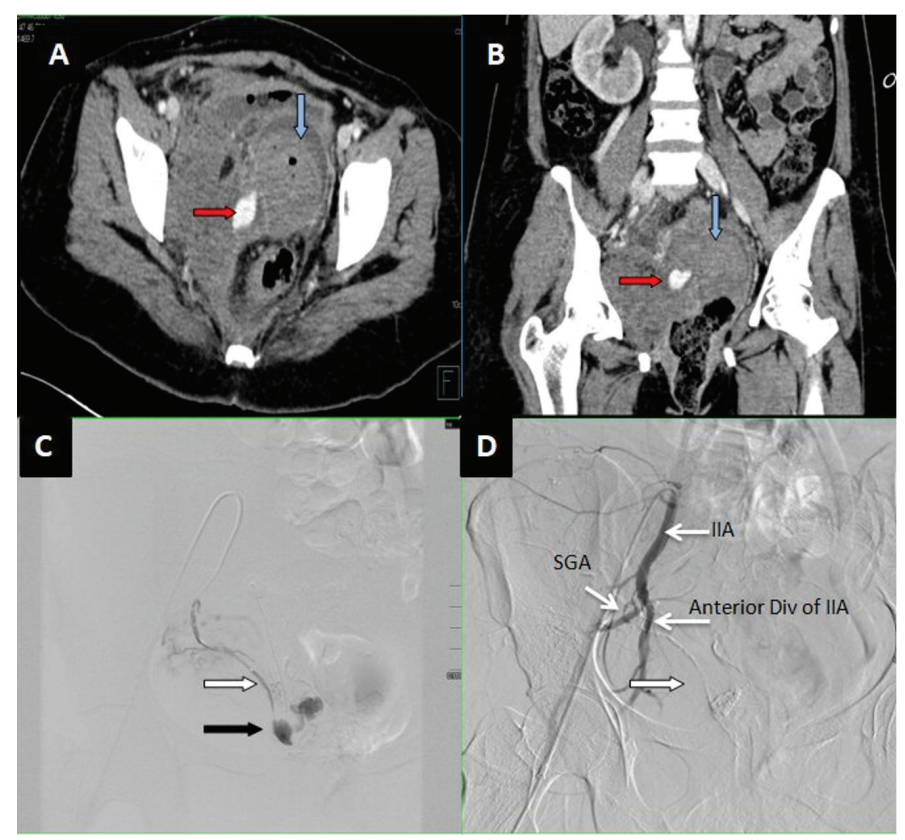

Figure 2. CT angiography images (A, B) showing pseudoaneurysm (red arrow) and surrounding hematoma (blue arrow) in the right lateral wall of the vagina. DSA spot images $(C, D)$ of the same patient showing pseudoaneurysm (black arrow) arising from the right vaginal artery (white arrow), which was embolized with a 30\% glue injection, and post embolization angiogram (D) showed nonfilling of pseudoaneurysm suggestive of successful embolization

IIA: Internal iliac artery, SGA: Superior gluteal artery, CT: Computed tomography
(Endocryl, Samarth Life Sciences Pvt. Ltd., India) (Figure 2C\&D). Post-procedure, the patient was transfused with one unit of PRBC. Post embolization, USG Doppler showed adequate blockage of the supplying artery. The vaginal pack was removed 48 hours after the procedure with no active bleeding. The patient remained hemodynamically stable and was discharged after seven days of embolization.

\section{Discussion}

Puerperal hematomas most commonly occur due to vascular injury in the lower genital tract, related to operative deliveries or episiotomy. However, hematomas may also result from injury to a blood vessel in the absence of laceration/incision of the surrounding tissue (e.g. pseudoaneurysm, traumatic arteriovenous fistula $)^{(3)}$. The incidence of puerperal hematomas in the literature is reported as 1:300 to 1:15,000 deliveries. They may present as pain and swelling at the episiotomy site or with profuse vaginal bleeding. There are three main approaches for managing episiotomy site hemorrhage: (1) Conservative management with observation and supportive care, (2) Surgical intervention and (3) Selective arterial embolization, depending on the clinical scenario. Smaller hematomas can be managed with a conservative approach; however, larger ones require surgical exploration. Sometimes, if a surgical repair fails or if there is a recurrent hematoma, embolization is the option for second-line management as in both of our cases. Another indication for which embolization has been used is uncontrolled hemorrhage following delivery due to genital tract injury.

Takagi et al.(4) reported that large and growing hematomas required surgical intervention and hemostasis was mostly obtained by ligation of the bleeding vessels and obliterating the dead space followed by vaginal packing for compression. However, sometimes identification of the bleeding vessel may be difficult leading to excessive bleeding and recurrent hematoma formation, requiring blood transfusion and embolization as a second-line treatment, as happened in our first case where recurrent hematoma formed and no active bleeder was found on surgical exploration ${ }^{(5,6)}$.

In 1979, Brown et al. ${ }^{(7)}$ reported first the case of intractable pelvic hematoma managed by embolization after the failure of three surgical attempts. Villela et al. ${ }^{(8)}$ reported two cases of vulvovaginal hematoma managed successfully by embolization as a second-line treatment. In one case, embolization was performed after a failed surgical management, and in the other, vaginal packing was performed to achieve hemostasis in a hematoma that formed after a vacuum delivery; hemostasis could not be achieved so selective artery embolization was performed, which successfully controlled the bleeding. In a retrospective review conducted by Lee et al. ${ }^{(9)}$ on 60 patients who underwent embolization primarily due to unmanageable genital tract injury bleeding, post-delivery, it was reported that the clinical success rate was $88 \%(53 / 60)$ after the first embolization and 97\% (58/60) after the second embolization. 
Some other authors have also reported selective arterial embolization as a first-line treatment for intractable and large hematomas after an evaluation by enhancing CT to identify the location of hematoma and the exact source of bleeding ${ }^{(4,5)}$. This may help in diagnosing some rare cause of episiotomy site hemorrhage such as AV malformation and pseudoaneurysm, which may present along with hematoma, as in our second case. Pseudoaneurysms are a rare complication that may occur due to inadequate repair of injury to an arterial wall due to trauma, which may be surgical. Most post-partum pseudoaneurysms have been described in the uterine artery, and it is quite rare at other locations such as the vagina. Few cases of vaginal pseudoaneurysm managed by selective artery embolization have been reported involving different arteries such as the vaginal artery, left internal pudendal artery, left obturator artery, and the labial artery ${ }^{(2,3,10)}$. The definitive diagnosis of pseudoaneurysm is made by angiography; however, both USG Doppler or contrast CT can be useful for its detection, as in our second case, and in monitoring the size of an unruptured pseudoaneurysm. The diagnosis of pseudoaneurysm on USG is based on the presence of a cystic mass showing pulsation and Doppler showing turbulent a blood flow pattern often in association with a to-and-fro waveform pattern ${ }^{(3,11)}$.

In cases of recurrent vaginal hematoma and pseudoaneurysm, the cause is mostly failed surgical management or tissue trauma leading to its friability and inadequate hemostasis as documented in both of our cases. Early diagnosis and intervention in the form of embolization help in decreasing patient morbidity. There is a lack of data in the literature regarding the investigation of choice, at present, however, CT angiography is the investigation of choice to delineate detailed anatomy of pelvic vasculature and to identify any leaking point if present, in cases of episiotomy site hemorrhage ${ }^{(4,10)}$.

\section{Conclusion}

In patients presenting with recurrent episiotomy site hematoma after failed surgical management, the possibility of rupture pseudoaneurysm should be kept in mind and evaluated promptly. Selective artery embolization should be considered as a therapeutic option in such patients after confirmation by a proper imaging technique or instantly in emergencies. It helps in decreasing morbidity of the patient by decreasing surgical complication, the number of blood transfusions, ICU and overall hospital stay.

\section{Ethics}

Informed Consent: Retrospective study.

Peer-review: Externally peer-reviewed.

\section{Authorship Contributions}

Surgical and Medical Practices: S.S., J.M., S.K., S.G., Concept: S.S., J.M., S.K., S.G., Design: S.S., J.M., S.K., S.G., Data Collection or Processing: S.S., J.M., S.K., S.G., Analysis or Interpretation: S.S., J.M., S.K., S.G., Literature Search: S.S., J.M., S.K., S.G., Writing: S.S., J.M., S.K., S.G.

Conflict of Interest: The authors declare no conflict of interest. Financial Disclosure: The authors declared that this study received no financial support.

\section{References}

1. Cooper BC, Hocking-Brown M, Sorosky JI, Hansen WF. Pseudoaneurysm of the uterine arteryrequiring bilateral uterine artery embolization. J Perinatol 2004;24:560-2.

2. Gondo S, Urushiyama D, Yoshizato T, Kora S, Maehara M, Kondo $\mathrm{H}$, et al. The successful detection of postpartum unruptured vaginal pseudoaneurysm using ultrasonography: a case report. Springerplus 2014;3:482

3. Nagayama C, Gibo M, Nitta H, Uezato T, Hirakawa M, Masamoto H et al. Rupture of pseudoaneurysm after vaginal delivery successfully treated by selective arterial embolization. Arch Gynecol Obstet 2011;283:37-40.

4. Takagi K, Akashi K, Horiuchi I, Nakamura E, Samejima K, Ushijima $\mathrm{J}$, et al. Managing vulvovaginal hematoma by arterial embolization as first-line hemostatic therapy. Taiwan J Obstet Gynecol 2017;56:224-6.

5. Distefano M, Casarella L, Amoroso S, Di Stasi C, Scambia G, Tropeano G. Selectivearterial embolization as a first-line treatment for postpartum hematomas. Obstet Gynecol 2013;121:443-7.

6. Ojala K, Perala J, Kariniemi J, Ranta P, Raudaskoski T, Tekay A. Arterial embolizationand prophylactic catheterization for the treatment for severe obstetrichemorrhage. Acta Obstet Gynecol Scand 2005;84:1075-80.

7. Brown BJ, Heaston DK, Poulson AM, Gabertet HA, Mineau DE, Miller FJ Jr. Uncontrollable postpartum bleeding: a new approachto hemostasis through angiographic arterial embolization. Obstet Gynecol 1979;54:361-5.

8. Villella J, Garry D, Levine G, Glanz S, Figueroa R, Maulik D. Postpartum angiographicembolization for vulvovaginal hematoma. A report of two cases. J Reprod Med 2001;46:65-7.

9. Lee SM, Shin JH, Shim JJ, Yoon KW, Cho YJ, Kim JW, et al. Postpartum haemorrhage due to genital tract injury after vaginal delivery: safety and efficacy of transcatheter arterial embolisation. Eur Radiol 2018;28:4800-9.

10. Leaf MC, Schmidt L, Serna-Gallegos T, Lane F. A ruptured vulvar labial artery pseudoaneurysm causes a secondary postpartum hemorrhage: a case report. Case Rep Womens Health 2020;26:e00184. doi: 10.1016/j.crwh.2020.e00184.

11. Mahmoud MZ, Al-Saadi M, Abuderman A, Alzimami KS, Alkhorayef M, Almagli B, et al. "To-and-fro" waveform in the diagnosis ofarterialpseudoaneurysms. World J Radiol 2015;7:89-99. 